\title{
Esteya floridanum sp. nov.: An Ophiostomatalean Nematophagous Fungus and Its Potential to Control the Pine Wood Nematode
}

\author{
You Li, ${ }^{1}$ Haiying Yu, ${ }^{2,3}$ João P. M. Araújo, ${ }^{1}$ Xinfeng Zhang, ${ }^{2}$ Yingchao Ji, ${ }^{4}$ and Jiri Hulcr ${ }^{1, \dagger}$ \\ ${ }^{1}$ School of Forest Resources and Conservation, University of Florida, Gainesville, FL 32611, U.S.A. \\ ${ }^{2}$ Technology Center, General Station of Forest Pest Control, National Forestry Administration, Shenyang, Liaoning 110034, China \\ ${ }^{3}$ Shenyang Institute of Technology, Shenyang, Liaoning 113122, China \\ ${ }^{4}$ College of Plant Protection, Shandong Agricultural University, Tai'an 271018, China \\ Accepted for publication 28 July 2020.
}

\begin{abstract}
The nematophagous fungal genus Esteya is reported as a natural enemy of the pine wood nematode Bursaphelenchus xylophilus, which causes pine wilt in Asia and Europe. During a survey of fungi associated with ambrosia beetles in Florida, an undescribed Esteya species was found. A phylogenetic analysis based on nuclear large subunit and $\beta$-tubulin DNA sequences supported this isolate as a new species, E. floridanum. Morphological and phylogenetic characteristics and a species description are provided here. The fungus was observed to kill the pine wood nematode in vitro. To evaluate the ability of E. floridanum to protect trees against the pine wood nematode in vivo, the effect of prophylactic
\end{abstract}

ABSTRACT inoculation was tested on Pinus koraiensis and Larix olgensis in Liaoning, China. The results suggest that the fungus is not a plant pathogen and that it delays wilt and postpones death of two conifer trees. This presents a potential new avenue for research on biocontrol of pine wilt disease and stresses the value of research on pest organisms in their native regions.

Keywords: biological control, biotechnology, disease control, endophytic, forest pathology, invasive, Larix, nematodes, Ophiostomatalean fungi, parasite, pest management, Pinus, phylogeny
Pine wilt is a dramatic disease of susceptible conifers caused by the pine wood nematode (PWN) Bursaphelenchus xylophilus (Nematoda: Aphelenchoididae). PWN is not considered an economic pest in North American forests where it originates from (Bergdahl 1988). This parasite is widespread, causing pine wilt disease in Eastern Asia, first identified as the causal agent of this devastating disease on Asian pine in 1969 (Mamiya 1983; Tokushige and Kiyohara 1969). The ability of this nematode to rapidly spread in newly invaded habitats is attributed to its insect vectors, longhorn beetles of the genus Monochamus (Wang et al. 2014; Zhang et al. 2007). Once within the tree tissues, the nematodes proliferate and move actively throughout the tree until they eventually encounter a new beetle vector (Kobayashi et al. 1984).

The wilting disease of pine trees has been increasing since the $2000 \mathrm{~s}$ in a wide area of temperate and subtropical regions of Asia and Europe (Abelleira et al. 2020; Mota et al. 1999; Zhang et al. 2010). The results of regular management measures, such as direct cutting and burning of infested trees and fumigation of logs by pesticides, have not been satisfactory. Introductions of natural enemies of the PWN have been attempted, including the nematode endoparasitic fungus Esteya vermicola. This fungus was reported as a natural enemy of the PWN in Taiwan (Liou et al. 1999), showing

\section{†Corresponding author: J. Hulcr; hulcr@ufl.edu}

Funding: This research was supported by grants from the Liaoning Provincial Key Project of Research and Development Program (2019JH2/10200001), the Liaoning Provincial Key Research and Development Guidance Program (2019JH8/ 10200010), and the National Science Foundation (DEB-556283). The University of Florida team was funded by the U.S. Department of Agriculture (USDA) Animal and Plant Health Inspection Service, the USDA Forest Service, and the National Science Foundation.

*The $e$-Xtra logo stands for "electronic extra" and indicates there are supplementary materials published online.

The author(s) declare no conflict of interest.

(c) 2021 The American Phytopathological Society significant potential as a biological agent against the PWN in laboratory and field evaluations (Wang et al. 2018).

The genus Esteya was described more than 20 years ago but still includes only a single species, E. vermicola (Liou et al. 1999; Wang et al. 2014). E. vermicola is the only known nematophagous fungus in the order Ophiostomatales (Dreaden et al. 2014), which represent a polyphyletic group of tree- or wood-infecting fungi and are commonly vectored by bark and ambrosia beetles (Chang et al. 2017; Jankowiak et al. 2019). Phylogenetically, the genus Esteya is sister to the Raffaelea sulphurea complex, which accommodates fungi specifically associated with ambrosia beetles, especially beetles in the subfamily Platypodinae (Dreaden et al. 2014; Simmons et al. 2016; Wang et al. 2019). So far, eight strains of E. vermicola are known to science and are distributed widely across the globe, including in Brazil, Czechia, Italy, the United States, Taiwan island, Japan, Korea, and mainland China (Chu et al. 2015; Kobayashi et al. 1984; Li et al. 2018; Wang et al. 2016, 2019). All of these strains have demonstrated the ability to endoparasitize the PWN and thus bear potential for biological control applications (Wang et al. 2008, 2018).

During a survey of fungi associated with pine ambrosia beetles in Florida in March 2017, we isolated an unusual Esteya fungus from the head of a Myoplatypus flavicornis ambrosia beetle in loblolly pine trees in Gainesville (Li et al. 2018). However, since there was no information on the fungal identity, its relationship with PWN was unknown. Its identity and biological and ecological characterization are important because the fungus could potentially antagonize with the PWN and thus deserves attention for several reasons. First, PWN is native to North America, sympatric with the new Esteya species (Figueiredo et al. 2013; Mallez et al. 2013). All Esteya strains previously tested to control PWN were found in Eurasia and South America, where there is no natural population of PWN (Wang et al. 2014, 2019). Second, the fungal species described here was isolated from one of the most common wood borers on the local pine plantation. Third, building a broader phylogenetic framework including ecologically distinct taxa is crucial to understand the biology and evolution 
of ophiostomatalean fungi. Therefore, the objectives of this study were to designate a new species for the genus Esteya based on morphological, ecological, and molecular data and to test its potential for use as a control agent for the PWN in North China.

\section{MATERIALS AND METHODS}

Fungus isolation. A sample was isolated from the head of a male adult of Myoplatypus flavicornis on loblolly pine in Austin Cary Forest, Gainesville, Florida (Li et al. 2018). A culture was made on potato dextrose agar (PDA) media (Becton, Dickinson and Company, Sparks, MD) amended with $0.05 \mathrm{~g} / \mathrm{liter}$ of cycloheximide (Harrington 1981). The fungal strains were shipped from the University of Florida to the Shenyang Institute of Technology (SIT) under a memorandum of understanding between the two institutions. Pure cultures of the fungus were deposited in the culture collection (CMW) of the Forestry and Agricultural Biotechnology Institute at the University of Pretoria in South Africa.

Nematode isolation. The PWN for testing was isolated from a sick Korean pine (Pinus koraiensis) in Qingyuan, Fushun, Liaoning, China. PWN was identified in a previous study (Yu et al. 2019) and reared on the PDA media or potato dextrose water media.

DNA extraction, PCR amplification, and sequencing. Genomic DNA was extracted from the fungal culture grown on PDA, following the Extract-N-Amp Plant PCR kit (Sigma-Aldrich, St. Louis, MO) with the modification of using $3 \%$ bovine serum albumin in the place of a dilution solution.. Primer combinations used for PCR amplifications were as follows: (i) LR0R/LR5 (Hopple 1994; Vilgalys and Hester 1990) for nuclear large subunit (LSU) ribosomal DNA (rDNA), (ii) $\mathrm{Bt} 2 \mathrm{a} / \mathrm{Bt} 2 \mathrm{~b}$ (Glass and Donaldson 1995; O’Donnell and Cigelnik 1997) for $\beta$-tubulin ( $\beta$-tub), and (iii) ITS1F/ITS4 (Gardes and Bruns 1993; White et al. 1990) for portions of the internal transcribed spacer ITS1-5.8SITS2 (ITS) rDNA locus. PCR reactions contained the following: $1 \mu \mathrm{l}$ of template DNA, $1 \mu \mathrm{l}$ of forward and reverse primers $(10 \mathrm{mM})$, $12.5 \mu \mathrm{l}$ of Premix Taq polymerase (Takara ExTaq), $1 \mu$ l of dimethyl sulfoxide, and $9.5 \mu \mathrm{l}$ of molecular-grade DNA-free water. The PCR cycling conditions for ITS and $\beta$-tub were as follows: $1 \mathrm{~min}$ at $95^{\circ} \mathrm{C}$; 35 cycles of $94^{\circ} \mathrm{C}$ for $30 \mathrm{~s}, 53^{\circ} \mathrm{C}$ for $45 \mathrm{~s}$, and $72^{\circ} \mathrm{C}$ for $90 \mathrm{~s}$; and finally, $72^{\circ} \mathrm{C}$ for $5 \mathrm{~min}$. PCR cycling conditions for the LSU gene were as follows: $1 \mathrm{~min}$ at $95^{\circ} \mathrm{C} ; 35$ cycles of $95^{\circ} \mathrm{C}$ for $30 \mathrm{~s}, 55^{\circ} \mathrm{C}$ for $45 \mathrm{~s}$, and $72^{\circ} \mathrm{C}$ for $90 \mathrm{~s}$; and finally, $72^{\circ} \mathrm{C}$ for $10 \mathrm{~min}$. Amplified products were purified and Sanger sequenced by GENEWIZ (South Plainfield, NJ). Sequence chromatograms were edited and assembled in Geneious 9.0.5 (https://www.geneious.com/). Representative sequences for suspected new species were uploaded to GenBank (Supplementary Table S1, accession numbers LC363546, MT811023, and MT858361).

Alignment and phylogenetic analysis. The concatenated LSU plus $\beta$-tub (introns 3/4/5 removed) dataset was analyzed in
Geneious for phylogenetic reconstruction. The ITS sequences were not included in the phylogenetic analyses, as these sequences were only used for molecular identification (Supplementary Table S1). The phylogenetic analysis included the suspected new species in this study and reference isolates representing $E$. vermicola and other ophiostomatalean fungi related to the genus Esteya (Li et al. 2018; Musvuugwa et al. 2015; Simmons et al. 2016; Supplementary Table S1). The alignments were conducted using MAFFT (Katoh et al. 2019) and deposited in TreeBASE (treebase.org; Study ID: S26477). The Akaike information criterion in jModeltest 2.1.10 (Guindon and Gascuel 2003; Posada 2008) was used to select the nucleotide substitution model GTR $+\mathrm{I}+\mathrm{G}$ for both genes. Bayesian inference analyses were performed using MrBayes 3.2.6 (Ronquist and Huelsenbeck 2003), and maximum likelihood (ML) analyses were performed using the RAxML2.0 (Stamatakis 2014) plug-in in Geneious. ML phylogenetic analyses were conducted with bootstrap support (BS) values from 500 search replicates. Bayesian posterior probabilities (BPPs) were estimated with two chains, and each was executed simultaneously for 1,000,000 generations, sampling every 200 generations, and a burn-in of the first 100,000 trees. The best ML tree was edited in FigTree 1.4.3 (http:// tree.bio.ed.ac.uk/software/figtree) and Adobe Photoshop CS4 (https://www.adobe.com).

Growth trials and morphological characterization. To determine the optimal growth conditions of the new Esteya species, mycelial plugs ( $4 \mathrm{~mm}$ in diameter) were plated on new fresh PDA plates (90 $\mathrm{mm}$ in diameter) and incubated in the dark at 15, 20, 25, and $30^{\circ} \mathrm{C}$ for 8 days. For each temperature, five replicates were used. Colony diameter was measured after 5 and 8 days of incubation. Two colony diameters perpendicular to each other were averaged and means \pm standard deviations were calculated. Morphological features were examined by inoculating sterile slide mounts of malt extract agar (MEA; Becton, Dickinson and Company) with propagules collected by running a sterile needle along the surface of cultures growing on MEA. Once taxonomically informative structures were observed using a dissecting microscope ( 24 to $48 \mathrm{~h}$ ), slides were mounted and examined on a Leica DM2500 LED optical microscope using LAS X software (https://www.leica-microsystems.com). Measurements of conidiophores $(n=30)$ and two types of conidia $(n=30)$ were made and means \pm standard deviations were calculated.

Assay of controlling PWN on the media. To prepare the fungal inoculum, fungal isolates were cultured onto MEA plates at $25^{\circ} \mathrm{C}$ until fully colonized (approximately 2 weeks), then the fungal spores and hyphae on the surface of media were scraped with $5 \mathrm{ml}$ of water and transferred to a clean Petri dish. One milliliter of PWN in water (approximately 1,500 individuals) was also added to this Petri dish and to an empty Petri dish as a negative control. Then, the Petri dishes were preserved in an incubator at $25^{\circ} \mathrm{C}$ for 30 days. Sterile water was added to each plate every few days to maintain humidity. The mortality

TABLE 1. Inoculation of two conifer trees

\begin{tabular}{|c|c|c|c|c|c|c|}
\hline \multirow[b]{2}{*}{ Species } & \multirow[b]{2}{*}{ Treatment no. } & \multirow[b]{2}{*}{ Seedlings $(n)$} & \multicolumn{2}{|c|}{ Treatment $^{\mathrm{a}}$} & \multicolumn{2}{|c|}{ Mortality (\%) } \\
\hline & & & First inoculum & Second inoculum & 14 weeks & Ultimate \\
\hline \multirow[t]{3}{*}{ Larix olgensis } & 1 & 20 & Esteya floridanum & N/A & 0 & 0 \\
\hline & 2 & 20 & Sterile water & N/A & 0 & 0 \\
\hline & 4 & 20 & N/A & PWN & 100 & 100 \\
\hline \multirow[t]{2}{*}{ Pinus koraiensis } & 5 & 20 & E. floridanum & N/A & 0 & 0 \\
\hline & 6 & 20 & Sterile water & N/A & 0 & 0 \\
\hline
\end{tabular}

${ }^{\mathrm{a}} \mathrm{N} / \mathrm{A}=$ no second inoculum and $\mathrm{PWN}=$ pine wood nematode. 
rate of adult PWN was counted from 100 randomly selected individuals under an inverted biological microscope (Optec BDS400).

Assay of controlling PWN within conifer trees. Seedlings of healthy Korean pine ( $P$. koraiensis) and Olga Bay larch (L. olgensis) were provided by Cangshi Forest Farm in Fushun, Shenyang, China. We performed our nematophagous tests on small, containerized trees (1-gallon pot) with an initial height of approximately 0.3 to $0.4 \mathrm{~m}$ of 4 -year-old Korean pine and 0.4 to $0.5 \mathrm{~m}$ of 2-year-old Olga Bay larch. Individual trees within each species were of similar size. These two tree species were selected because (i) Korean pine and Olga Bay larch are dominant tree species in Northeastern China and are of ecological as well as economic significance and (ii) PWN causes serious damage to both tree species (Pan et al. 2019; Yu et al. 2019). Eighty seedlings of each species were grown and tested in a quarantine greenhouse facility at the SIT. In the greenhouse, trees were individually inspected and monitored for 2 weeks to test for the absence of any existing pathogens or pests prior to inoculation. The trees were maintained under natural light, $40 \% \mathrm{RH}$, and at an average temperature of 8 to $10^{\circ} \mathrm{C}$ at night and 20 to $25^{\circ} \mathrm{C}$ in the daytime in the winter. The trees were watered every 2 days without additional treatments (e.g., fertilization).

Forty randomly chosen individuals of each tree species were prophylactically inoculated with the new Esteya species on 11 October 2019 (Table 1). A wound at a $80^{\circ}$ downward angle on the phloem of each seedling was cut with a sterile scalpel. Wounds were made within the basal $5 \mathrm{~cm}$ of the stem and were up to $1 \mathrm{~cm}$ deep. Then, the wounds were filled with a sterile folded gauze $(2 \times 2 \mathrm{~cm})$ inoculated with $1 \mathrm{ml}$ of spore suspension by pipette (approximately $10^{6}$ spores). Wounds and gauze were wrapped in parafilm immediately to avoid crosscontamination.
Two weeks after inoculation with the fungus, half of the fungalinoculated trees $(n=20)$ and noninoculated trees $(n=20)$ were inoculated with the PWN solution (approximately 1,000 nematodes per tree) following the same method as above except the wounds were made within the basal $7 \mathrm{~cm}$ of the stem. Controls $(n=20)$ were treated in the same manner as the inoculated trees, except that only sterile water was inoculated.

Seedlings were monitored for 12 weeks after fungal inoculation in the greenhouse. All signs and symptoms of pathogenic development (including resin bleeding, wilt, and mortality) were recorded every week. To confirm the survival of the fungal inoculum, fungi were reisolated from the branch and trunk surrounding the inoculation site on 10 randomly selected pine trees, if the tree was surviving. The sampled wood tissues were rinsed in sterile water, blotted dry, and plated onto PDA plates incubated at $25^{\circ} \mathrm{C}$. Subcultures were plated onto PDA and identified using morphology.

\section{RESULTS}

The phylogenetic analyses of the combined LSU rDNA and $\beta$-tub data matrices by ML and Bayesian inference were highly similar and led to the same conclusion. The placement of E. floridanum sp. nov. as a sister species to $E$. vermicola was strongly supported $(\mathrm{BS}=$ $99, \mathrm{BPP}=100)$. Our results also strongly suggested $(\mathrm{BS}=99, \mathrm{BPP}=$ 100 ) that the genus Esteya is sister to the R. sulphurea complex (Fig. 1, Supplementary Figure S1).

Taxonomy. E. floridanum $Y$. Li, Araújo \& Hulcr, sp. nov. E. floridanum Y. Li, Araújo \& Hulcr, sp. nov. was deposited in MycoBank (MB 835374; Fig. 2). Colonies were initially white, turning gray after 5 days; reverse initially white, aging to brown on PDA and beige on MEA. Colonies grew on PDA at an average rate

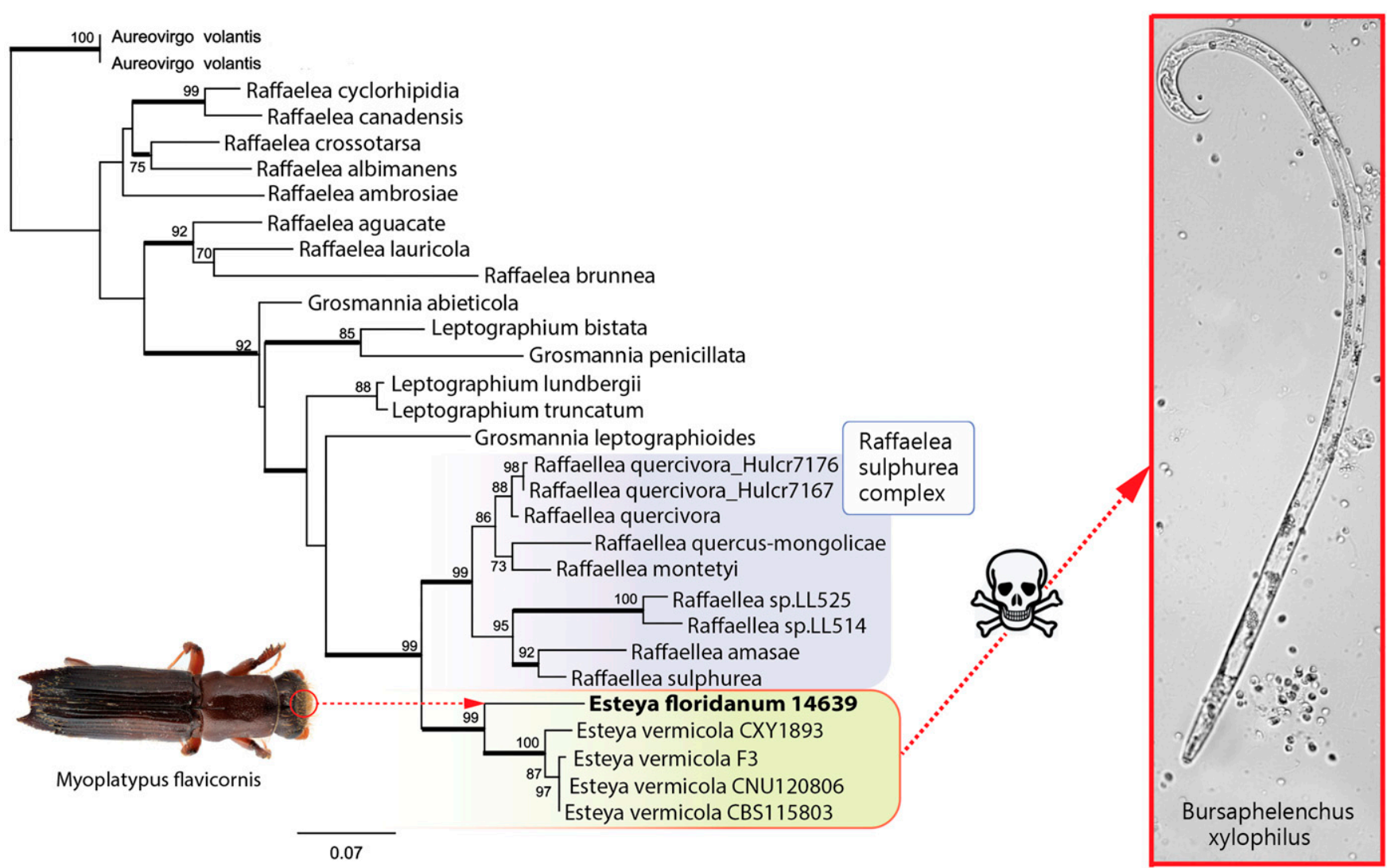

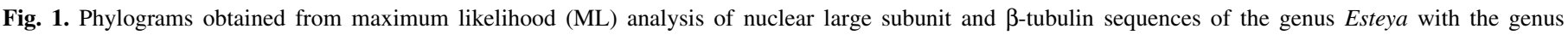

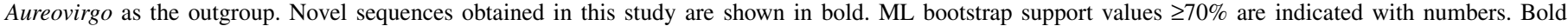
branches indicate Bayesian posterior probability support $\geq 0.95$. The photograph of the beetle is from A. J. Johnson. 
of $0.51 \pm 0.16 \mathrm{~mm} /$ day at $10^{\circ} \mathrm{C}, 1.53 \pm 0.30 \mathrm{~mm} /$ day at $15^{\circ} \mathrm{C}, 2.91 \pm$ $0.34 \mathrm{~mm} /$ day at $20^{\circ} \mathrm{C}, 2.73 \pm 0.68 \mathrm{~mm} /$ day at $25^{\circ} \mathrm{C}$, and $3.33 \pm$ $0.33 \mathrm{~mm} /$ day at $30^{\circ} \mathrm{C}$; there was no growth at $35^{\circ} \mathrm{C}$.

The mycelium produced two types of conidiophores: conidiogenous cells and conidia (see Fig. 2E and G). The first type of conidiophores were macronematous, mononematous, unbranched, erect, ampulliform, septate, subhyaline to light brown, asymmetrical, smooth. Conidiogenous cells were terminal, (11-) $17(-35) \times(-3) 3.5(4.4) \mu \mathrm{m}$, swollen at the base tapering upward into a neck, 4.5 to $7 \times 1.5$ to $2 \mu \mathrm{m}$ phialidic, usually supported by a short-swollen cell. Conidia were solitary, one-celled, lunate, apiculate ends, hyaline, smooth-walled, 6.5 to $10.5 \times 2.3$ to $4.9 \mu \mathrm{m}$, containing an endospore-like structure 4 to $5 \times 2$ to $2.5 \mu \mathrm{m}$, adhesive.

The second type of conidiophores were macronematous, mononematous, simple or branched, erect, irregular, subhyaline to light brown, septate, swollen at the base irregularly tapering toward the apex, smooth to roughened, (22-) 30 (43-) $\times(3.2-) 3.8$ $(-4.2) \mu \mathrm{m}$. Conidiogenous cells were phialidic, enteroblastic, often terminal but also intercalary, usually swollen at the base tapering toward the apex, 14 to $20 \times 3$ to $4.5 \mu \mathrm{m}$. Conidia were solitary, onecelled, cylindrical, ellipsoidal to hemispherical, hyaline, smooth, (3.4-) $5.2(-7.1) \times(-1.9) 2.8(-3.6) \mu \mathrm{m}$, commonly dividing by budding after release.

No teleomorphic (sexual) phase was observed.

Etymology. Etymology refers to the locality of the holotype, Florida.

Type. USA: Florida: Gainesville, Austin Cary Forest (29.717321 $\mathrm{N},-82.241621 \mathrm{~W})$, from the head of ambrosia beetle Myoplatypus flavicornis (Coleoptera: Curculionidae: Platypodinae) in a loblolly pine P. taeda. Collector: Y. Li. Date: 5 March 2017 (CMW55942ex-holotype).

In vitro assay of PWN control. After E. floridanum was released into the PWN culture in the plate, 97\% of PWNs were

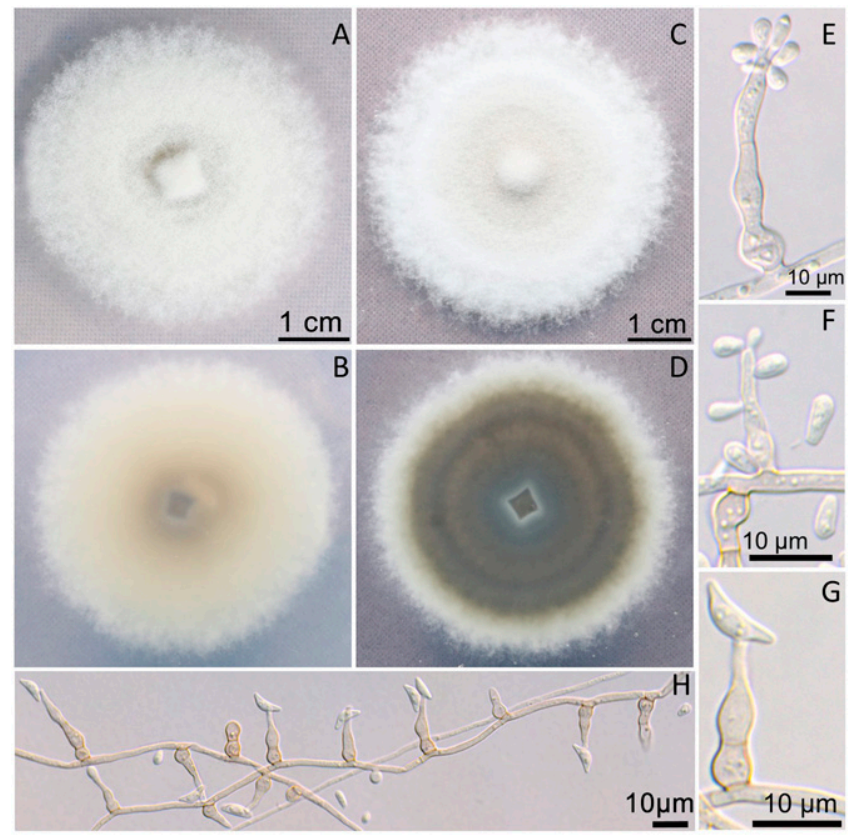

Fig. 2. Esteya floridanum morphological features in pure culture on $\mathbf{A}, \mathbf{B}, \mathbf{E}, \mathbf{F}$, $\mathbf{G}$, and $\mathbf{H}$, malt extract agar (MEA) and $\mathbf{C}$ and $\mathbf{D}$, potato dextrose agar (PDA) and two types of conidia. A and B, Upper and reverse of culture growth after $14 \mathrm{~d}$ at $25^{\circ} \mathrm{C}$ on MEA. C and D, Upper and reverse of culture growth after 14 $\mathrm{d}$ at $25^{\circ} \mathrm{C}$ on PDA. E and F, Hyphae bearing long, flask-shaped conidiogenous cells with conidia at the apex and occasional sessile lateral conidia. $\mathrm{G}$ and $\mathrm{H}$, Hyphae bearing long, flask-shaped conidiogenous cells with lunate conidia at the apex. parasitized (Fig. 3) and ultimately killed by E. floridanum after 30 days, whereas $69 \%$ of PWNs survived in the controls.

Both tree species inoculated only with E. floridanum (Table 1, treatments 1 and 5) or sterile water (Table 1, treatments 2 and 6) but no PWN survived and displayed no symptoms of poor health. In the pine trees inoculated with E. floridanum, the strains were reisolated from the three trees after 12 weeks.

All seedlings inoculated with PWN showed serious wilt before ultimately dying after 14 weeks (treatments 3 to 4 and 7 to 8; Figs. 4C, F, I, and L and 5). Representative characteristics of external symptoms are shown in Figure 4. Wilt started earlier and progressed more rapidly on Korean pine than on Olga Bay larch. Seventy-five percent of Korean pine seedlings wilted 2 weeks after inoculation with PWN. Leaf drooping was not observed on Korean pine, but defoliation occurred rapidly in larch after wilt (Fig. 4E and F).

For both conifer seedlings, treatment with E. floridanum deferred wilt for 2 to 4 weeks and death for 4 to 6 weeks, respectively. For instance, all seedlings untreated with E. floridanum and then inoculated with PWN died within the experimental period, whereas

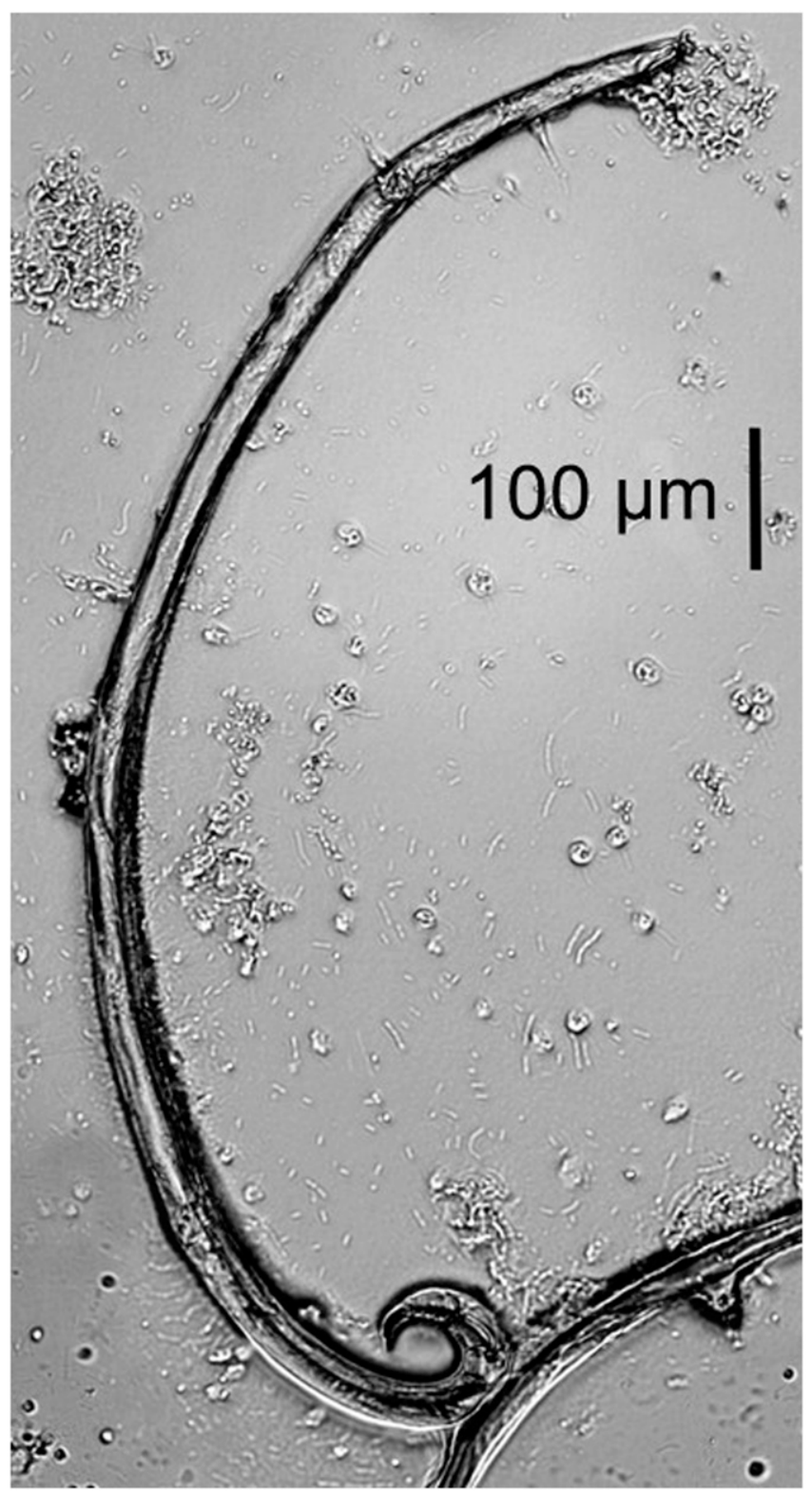

Fig. 3. Pine wood nematode killed by Esteya floridanum. 
only $50 \%$ of larch and $35 \%$ of Korean pine died within 8 weeks after inoculation of PWN and E. floridanum (Fig. 5).

\section{DISCUSSION}

E. floridanum is the second described species in the genus Esteya. This genus has remained monotypic since its discovery (Liou et al.
1999). Our discovery of this new species suggests that the true diversity of nematophagous fungi, especially within Ophiostomatales, is still unknown and the genus Esteya could potentially harbor a reservoir of undocumented species with potential to become effective agents against pine wilt disease.

Similar to E. vermicola, E. floridanum also produces two types of conidia, both observed to attach to nematodes (Fig. 3). This

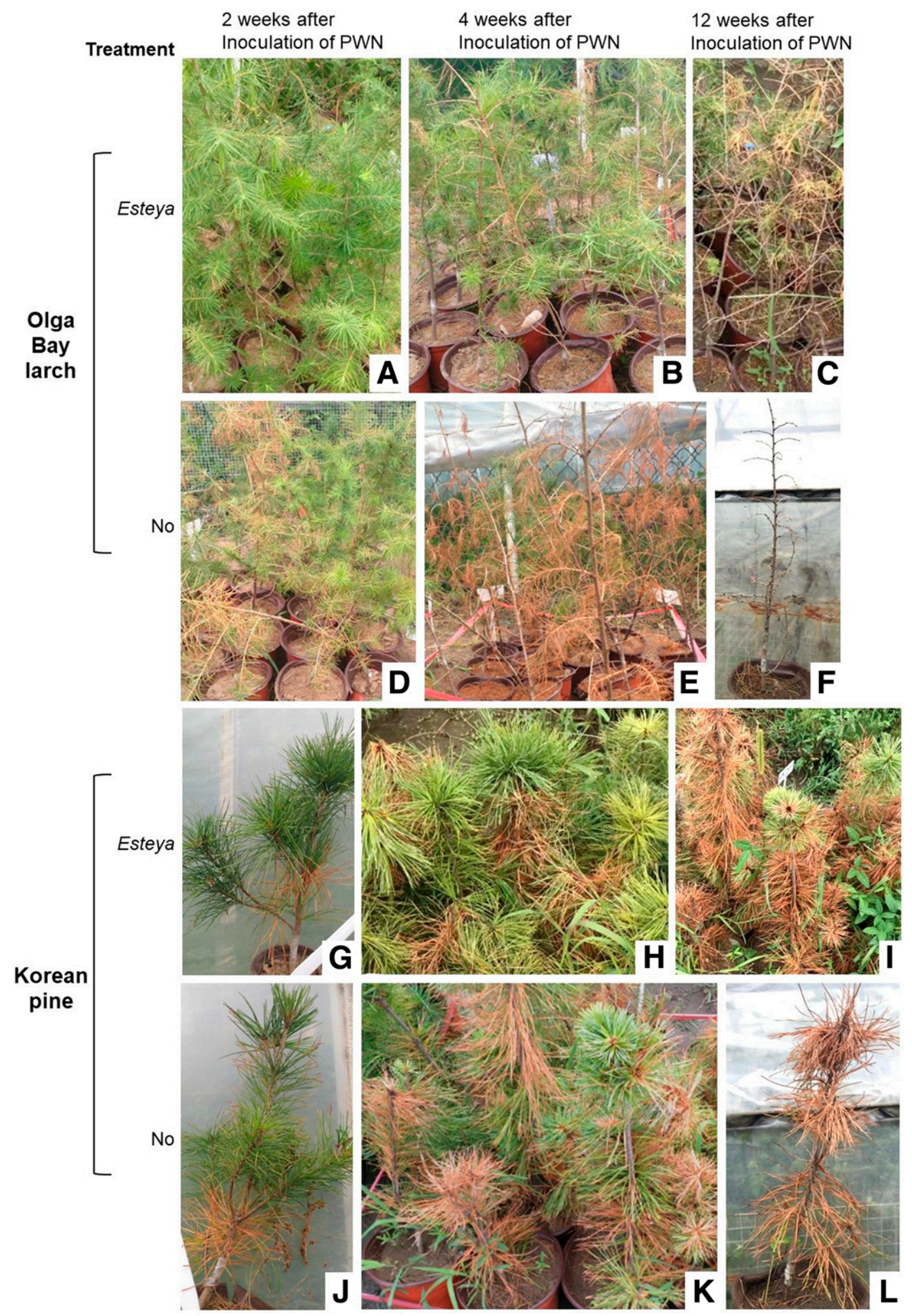

Fig. 4. Conifer seedlings inoculated with the pine wood nematode $(\mathrm{PWN})$. A, D, G, and J, Two weeks later. B, E, H, and K, Four weeks later. C, F, I, and L, Twelve weeks later. 
characteristic is unique to the genus Esteya among ophiostomatalean fungi and supports the placement of the new fungal species within the genus Esteya from an ecological perspective. Regarding morphology, both Esteya species are morphologically very similar. However, while conidiogenous cells of E. vermicola are formed directly on the main vegetative hypae, conidiogenous cells of E. floridanum are often supported by a short, swollen cell, which connects it to the main hyphae (Fig. $2 \mathrm{G}$ and $\mathrm{H}$ ). Both E. vermicola and $E$. floridanum produce two types of similar conidia, but type 2 of E. floridanum is wider (see Table 2). Our molecular data also strongly support E. floridanum as an Esteya species, sister to E. vermicola (Fig. 1).

The results of our phylogenetic analyses were in agreement with analogous studies by Li et al. (2018) and Simmons et al. (2016), which showed the genus Esteya and the $R$. sulphurea complex as sister clades within Leptographium sensu lato (Fig. 2). Interestingly, the genus Esteya represents a drastic ecological shift within the
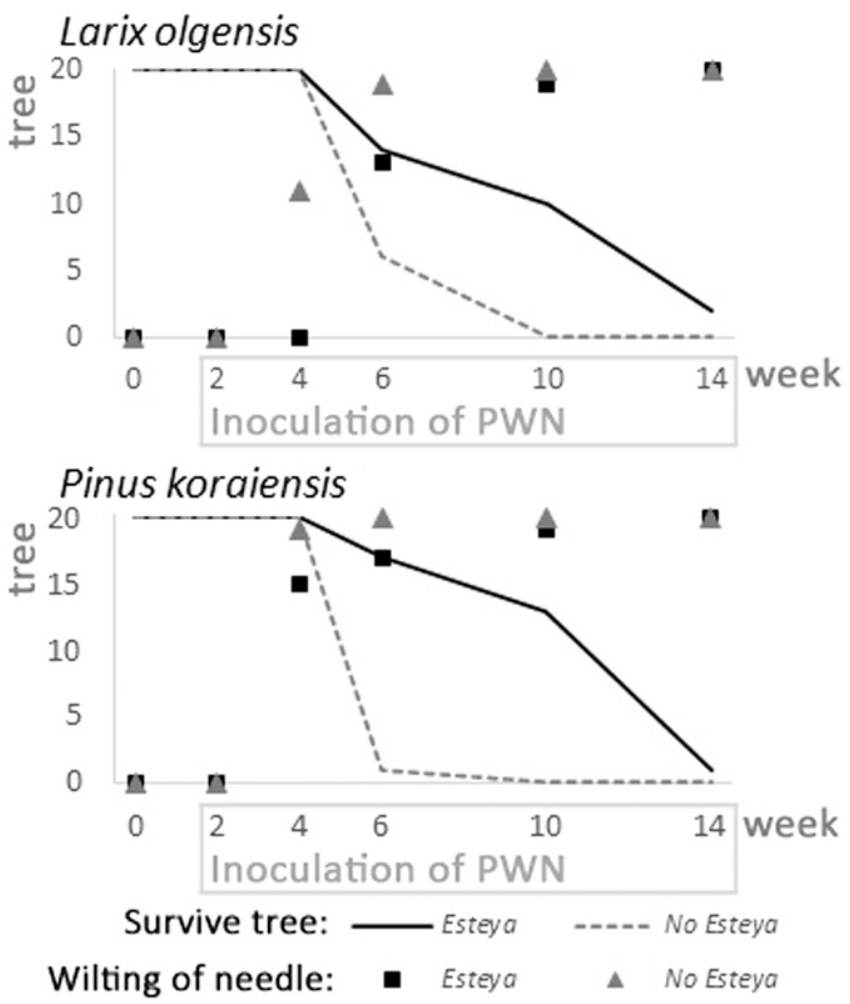

Fig. 5. Survival of conifer seedlings inoculated with the pine wood nematode (PWN; treatments 3 to 4 and 7 to 8 ) and Esteya floridanum. order Ophiostomatales, an interkingdom host switch from plantbased nutrition, which is the most common ecology across ophiostomatalean species, to become a nematophagous fungus (Fig. 3). It is parsimonious to propose that such a transition occurred as a result of niche overlap, since the nematodes live inside the trees and thus encounter of both organisms is likely to occur. In addition, both organisms use beetles for transport from one host tree to another, considerably increasingly the likelihood of encounter. This example could be framed from the perspective of the "host habitat hypothesis," which suggests that microhabitats and feeding habitats promote the encounter of both organisms, facilitating an eventual transition from one host to another (Araújo and Hughes 2019; Nikoh and Fukatsu 2000).

Our results also showed that E. floridanum could infect the PWN in culture (Fig. 3). E. floridanum showed a similar infection process as that of the E. vermicola strain (Wang et al. 2014). Only lunate conidia were available to attach to nematode and germinate from cadavers.

Considering that the new species is not known to occur in Asia and that numerous members in the $R$. sulphurea complex and genus Leptographium are tree pathogens, it was essential to test the biological security of a potential introduction of this fungus in Northern China before evaluating the inhibiting effect on PWN. None of the pine and larch exhibited any health impacts or death after inoculation. This indicates that $E$. floridanum is not a pathogen to conifer trees in North China. Because E. floridanum was recovered after 14 weeks, it may grow as an endophytic fungus within living trees.

E. floridanum presented limited ability to inhibit the PWN in pine and larch. Almost all inoculated trees were finally killed by the nematode. We observed that the tree inoculated with E. floridanum in advance was wilted a few weeks later than the noninoculated treatment tree. Death of seedlings may be accelerated as a result of their young stage, at which they usually are more sensitive to pathogens (Rabiey et al. 2019). Delayed wilt and death was more obvious in larch than pine. These data suggested that E.floridanum took effect on the plant. Before this study, the only field example of applying E. vermicola to combat PWN was conducted on large pine tree (Wang et al. 2018). This type of live tree test is essential for the assessment of the protective effects of the genus Esteya on conifers. Further work is being conducted in this area on expanding the trials to mature trees and with varied environmental conditions.

The discovery of a new Esteya species suggests that there may be additional nematophagous fungi in Ophiostomatales. About half of the recorded Esteya strains were isolated from bark and ambrosia beetle microhabitats. Those habitats have been cited repeatedly as a main source for fungal diversity and fungi with various symbiotic or biocidal effects (Blackwell 2011; Hawksworth and Lücking 2017; Wijayawardene et al. 2020), of which microhabitats such as bark and ambrosia microhabitats are part.

TABLE 2. Comparison of two Esteya fungi

\begin{tabular}{llc}
\hline Characteristic & \multicolumn{1}{c}{ E. vermicola } & E. floridanum \\
\hline Type $1(\mu \mathrm{m})$ & & $(11-) 17(-35) \times(-3) 3.5(-4.4)$ \\
$\quad$ Conidiogenous cells & $(10-) 16-29(-62) \times(1.5-) 3-4.4$ & $6.5-10.5 \times 2.3-4.9$ \\
$\quad$ Conidia & $8.2-11.1 \times 3.5-3.7$ & $(22-) 30(-43) \times(3.2-) 3.8(-4.2)$ \\
Type $2(\mu \mathrm{m})$ & $(22.2-) 34.1-43 \times 3-4.4$ & $(3.4-) 5.2(-7.1) \times(-1.9) 2.8(-3.6)$ \\
$\quad$ Conidiogenous cells & $(-3) 4.4-7.4 \times 1.5-1.9$ & Myoplatypus flavicornis \\
Conidia & Oxoplatypus quadridentatus, & P. taeda \\
Beetle $($ vector $)$ & Scolytus intricatus, Tomicus yunnanensis & \\
Host plant & Olea eropaea, Pinus thunbergii, & United States (Florida) \\
& P. yunnanensis, Quercus petraea, & \\
Distribution & Q. polycarpa, Q. robur & \\
& Brazil, China, Czechia, Italy, Japan, Korea, \\
\end{tabular}




\section{ACKNOWLEDGMENTS}

We thank Mingliang Yin (South China Agricultural University) for providing advice and Yin-Tse Huang (Kyoto University) for assisting with photographing the cultures.

\section{LITERATURE CITED}

Abelleira, A. A., Perez-Otero, R., Aguín, C. O., Prado, P. A., and Salinero, C. C. 2020. First report of Bursaphelenchus xylophilus (Nematoda: Aphelenchoididae) on Monochamus galloprovincialis (Coleoptera: Cerambycidae) in Spain. Plant Dis. 104:1259. doi.org/10.1094/PDIS-04-19-0816-PDN

Araújo, J. P., and Hughes, D. P. 2019. Zombie-ant fungi emerged from nonmanipulating, beetle-infecting ancestors. Curr. Biol. 29:3735-3738.

Bergdahl, D. R. 1988. Impact of pinewood nematode in North America: Present and future. J. Nematol. 20:260-265.

Blackwell, M. 2011. The fungi: 1, 2, 3 ... 5.1 million species? Am. J. Bot. 98: 426-438.

Chang, R., Duong, T. A., Taerum, S. J., Wingfield, M. J., Zhou, X., and de Beer, Z. W. 2017. Ophiostomatoid fungi associated with conifer-infesting beetles and their phoretic mites in Yunnan, China. MycoKeys 28:19-64.

Chu, W., Dou, Q., Chu, H., Wang, H., Sung, C. K., and Wang, C. 2015. Research advance on Esteya vermicola, a high potential biocontrol agent of pine wilt disease. Mycol. Prog. 14:115.

Dreaden, T. J., Davis, J. M., De Beer, Z. W., Ploetz, R. C., Soltis, P. S., Wingfield, M. J., and Smith, J. A. 2014. Phylogeny of ambrosia beetle symbionts in the genus Raffaelea. Fungal Biol. 118:970-978.

Figueiredo, J., Simões, M. J., Gomes, P., Barroso, C., Pinho, D., Conceição, L., Fonseca, L., Abrantes, I., Pinheiro, M., and Egas, C. 2013. Assessment of the geographic origins of pinewood nematode isolates via single nucleotide polymorphism in effector genes. PLoS One 8:e83542.

Gardes, M., and Bruns, T. D. 1993. ITS primers with enhanced specificity for Basidiomycetes-application to the identification of mycorrhizae and rusts. Mol. Ecol. 2:113-118.

Glass, N. L., and Donaldson, G. C. 1995. Development of primer sets designed for use with the PCR to amplify conserved genes from filamentous ascomycetes. Appl. Environ. Microbiol. 61:1323-1330.

Guindon, S., and Gascuel, O. 2003. A simple, fast, and accurate algorithm to estimate large phylogenies by maximum likelihood. Syst. Biol. 52:696-704.

Harrington, T. C. 1981. Cycloheximide sensitivity as a taxonomic character in Ceratocystis. Mycologia 73:1123-1129.

Hawksworth, D. L., and Lücking, R. 2017. Fungal diversity revisited: 2.2 to 3.8 million species. Pages 79-95 in: The fungal kingdom. J. Heitman, B. J. Howlett, P. W. Crous, E. H. Stukenbrock, T. Y. James, and N. A. R. Gow, eds. American Society for Microbiology, Washington, DC.

Hopple, J. S., Jr. 1994. Phylogenetic investigations in the genus Coprinus based on morphological and molecular characters. Ph.D. thesis, Duke University, Durham, NC.

Jankowiak, R., Strzałka, B., Bilański, P., Kacprzyk, M., Wieczorek, P., and Linnakoski, R. 2019. Ophiostomatoid fungi associated with hardwoodinfesting bark and ambrosia beetles in Poland: Taxonomic diversity and vector specificity. Fungal Ecol. 39:152-167.

Katoh, K., Rozewicki, J., and Yamada, K. D. 2019. MAFFT online service: Multiple sequence alignment, interactive sequence choice and visualization. Brief. Bioinform. 20:1160-1166.

Kobayashi, F., Yamane, A., and Ikeda, T. 1984. The Japanese pine sawyer beetle as the vector of pine wilt disease. Annu. Rev. Entomol. 29:115135

Li, Y., Huang, Y.-T., Kasson, M. T., Macias, A. M., Skelton, J., Carlson, P. S., Yin, M., and Hulcr, J. 2018. Specific and promiscuous ophiostomatalean fungi associated with Platypodinae ambrosia beetles in the southeastern United States. Fungal Ecol. 35:42-50.

Liou, J. Y., Shih, J. Y., and Tzean, S. S. 1999. Esteya, a new nematophagous genus from Taiwan, attacking the pinewood nematode (Bursaphelenchus xylophilus). Mycol. Res. 103:242-248.

Mallez, S., Castagnone, C., Espada, M., Vieira, P., Eisenback, J. D., Mota, M., Guillemaud, T., and Castagnone-Sereno, P. 2013. First insights into the genetic diversity of the pinewood nematode in its native area using new polymorphic microsatellite loci. PLoS One 8:e59165.

Mamiya, Y. 1983. Pathology of the pine wilt disease caused by Bursaphelenchus xylophilus. Annu. Rev. Phytopathol. 21:201-220.

Mota, M. M., Braasch, H., Bravo, M. A., Penas, A. C., Burgermeister, W., Metge, K., and Sousa, E. 1999. First report of Bursaphelenchus xylophilus in Portugal and in Europe. Nematology 1:727-734.

Musvuugwa, T., de Beer, Z. W., Duong, T. A., Dreyer, L. L., Oberlander, K. C., and Roets, F. 2015. New species of Ophiostomatales from Scolytinae and Platypodinae beetles in the Cape Floristic Region, including the discovery of the sexual state of Raffaelea. Antonie van Leeuwenhoek 108:933-950.
Nikoh, N., and Fukatsu, T. 2000. Interkingdom host jumping underground: Phylogenetic analysis of entomoparasitic fungi of the genus Cordyceps. Mol. Biol. Evol. 17:629-638.

O’Donnell, K., and Cigelnik, E. 1997. Two divergent intragenomic rDNA ITS2 types within a monophyletic lineage of the fungus Fusarium are nonorthologous. Mol. Phylogenet. Evol. 7:103-116.

Pan, L., Li, Y., Liu, Z., Meng, F., Chen, J., and Zhang, X. 2019. Isolation and identification of pine wood nematode in Pinus koraiensis in Fengcheng. Liaoning Prov. For. Pest Dis. 38:1-4.

Posada, D. 2008. jModelTest: Phylogenetic model averaging. Mol. Biol. Evol. 25:1253-1256

Rabiey, M., Hailey, L. E., Roy, S. R., Grenz, K., Al-Zadjali, M. A., Barrett, G. A., and Jackson, R. W. 2019. Endophytes vs tree pathogens and pests: Can they be used as biological control agents to improve tree health? Eur. J. Plant Pathol. 155:711-729.

Ronquist, F., and Huelsenbeck, J. P. 2003. MrBayes 3: Bayesian phylogenetic inference under mixed models. Bioinformatics 19:1572-1574.

Simmons, D. R., de Beer, Z. W., Huang, Y.-T., Bateman, C., Campbell, A. S., Dreaden, T. J., Li, Y., Ploetz, R. C., Black, A., and Li, H.-F. 2016. New Raffaelea species (Ophiostomatales) from the USA and Taiwan associated with ambrosia beetles and plant hosts. IMA Fungus 7:265-273.

Stamatakis, A. 2014. RAxML version 8: A tool for phylogenetic analysis and post-analysis of large phylogenies. Bioinformatics 30:1312-1313.

Tokushige, Y., and Kiyohara, T. 1969. Bursaphelenchus sp. in the wood of dead pine trees. J. Jpn. For. Soc. 51:193-195.

Vilgalys, R., and Hester, M. 1990. Rapid genetic identification and mapping of enzymatically amplified ribosomal DNA from several Cryptococcus species. J. Bacteriol. 172:4238-4246.

Wang, C. Y., Fang, Z. M., Sun, B. S., Gu, L. J., Zhang, K. Q., and Sung, C. K. 2008. High infectivity of an endoparasitic fungus strain, Esteya vermicola, against nematodes. J. Microbiol. 46:380-389.

Wang, C. Y., Yin, C., Fang, Z. M., Wang, Z., Wang, Y. B., Xue, J. J., Gu, L. J., and Sung, C. K. 2018. Using the nematophagous fungus Esteya vermicola to control the disastrous pine wilt disease. Biocontrol Sci. Technol. 28:268-277.

Wang, H., Chu, H., Xie, Q., Dou, Q., Feng, H., Yang, C., and Wang, C. 2016. Variation in sporulation of four Esteya vermicola isolates and their Infectivity against pinewood nematode. Sci. Silvae Sin. 52:139-146.

Wang, H., Wang, Z., Liu, F., Wu, C., Zhang, S., Kong, X., Decock, C., Lu, Q., and Zhang, Z. 2019. Differential patterns of ophiostomatoid fungal communities associated with three sympatric Tomicus species infesting pines in southwestern China, with a description of four new species. MycoKeys 50:93-133.

Wang, X., Wang, T., Wang, J., Guan, T., and Li, H. 2014. Morphological, molecular and biological characterization of Esteya vermicola, a nematophagous fungus isolated from intercepted wood packing materials exported from Brazil. Mycoscience 55:367-377.

White, T. J., Bruns, T. D., Lee, S. B., and Taylor, J. W. 1990. Amplification and direct sequencing of fungal ribosomal RNA genes for phylogenetics. Pages 315-322 in: PCR protocols: A guide to methods and applications. M. A. Innis, D. H. Gelfand, J. J. Sninsky, and T. J. White, eds. Vol. 18. Academic Press, San Diego, CA.

Wijayawardene, Hyde, N. N., K. D., Al-Ani, L. K. T., Tedersoo, L., Haelewaters, D., K., Rajeshkumar C., Zhao, R. L., Aptroot, A., Leontyev, V. D., Saxena, R. K., Tokarev, Y. S., Dai, D. Q., Letcher, P. M., Stephenson, S. L., Ertz, D., Lumbsch, H. T., Kukwa, M., Issi, V. I., Madrid, H., Phillips, A. J. L., Selbmann, L., Pfliegler, W. P., Horvath, E., Bensch, K., Kirk, P. M., Kolarikova, K., Raja, H. A., Radek, R., Papp, V., Dima, B., Ma, J., Malosso, E., Takamatsu, S., Rambold, G., Gannibal, P. B., Triebel, D., Gautam, A. K., Avasthi, S., Suetrong, S., Timdal, E., Fryar, S. C., Delgado, G., Reblova, M., Doilom, M., Dolatabadi, S., Pawlowska, J. Z., Humber, R. A., Kodsueb, R., Sanchez-Castro, I., Goto, B. T., Silva, D. K. A., de Souza, F. A., Oehl, F. R., da Silva, G. A., Silva, I. R., Blaszkowski, J., Jobim, K., Maia, L. C., Barbosa, F. R., Fiuza, P. O., Divakar, P. K., Shenoy, B. D., Castaneda-Ruiz, R. F., Somrithipol, S., Lateef, A. A., Karunarathna, S. C., Tibpromma, S., Mortimer, P. E., Wanasinghe, D. N., Phookamsak, R., Xu, J., Wang, Y., Tian, F., Alvarado, P., Li, D. W., Kusan, I., Matocec, N., Masic, A., Tkalcec, Z., Maharachchikumbura, S. S. N., Papizadeh, M., Heredia, G., Wartchow, F., Bakhshi, M., Boehm, E., Youssef, N., Hustad, V. P., Lawrey, J. D., Santiago, A. L. C. M. A., Bezerra, J. D. P., Souza-Motta, C. M., Firmino, A. L., Tian, Q., Houbraken, J., Hongsanan, S., Tanaka, K., Dissanayake, A. J., Monteiro, J. S., Grossart, H. P., Suija, A., Weerakoon, G., Etayo, J., Tsurykau, A., Vazquez, V., Mungai, P., Damm, U., Li, Q. R., Zhang, H., Boonmee, S., Lu, Y. Z., Becerra, A. G., Kendrick, B., Brearley, F. Q., Motiejunaite, J., Sharma, B., Khare, R., Gaikwad, S., Wijesundara, D. S. A., Tang, L. Z., He, M. Q., Flakus, A., Rodriguez-Flakus, P., Zhurbenko, M. P., McKenzie, E. H. C., Stadler, M., Bhat, D. J., Liu, J. K., Raza, M., Jeewon, R., Nassonova, E. S., Prieto, M., Jayalal, R. G. U., Erdogdu, M., Yurkov, A., Schnittler, M., Shchepin, O. N., Novozhilov, Y. K., Silva-Filho, A. G. S., Gentekaki, E., Liu, P., Cavender, J. C., Kang, Y., Mohammad, S., Zhang, L. F., Xu, R. F., Li, Y. M., Dayarathne, M. C., Ekanayaka, A. H., Wen, T. C., Deng, C. Y., Pereira, O. L., Navathe, S., Hawksworth, D. L., Fan, X. L., 
Dissanayake, L. S., Kuhnert, E., and Thines, M. 2020. Outline of fungi and fungus-like taxa. Mycosphere 11:1060-1456.

Yu, H., Wu, H., Zhang, X., Wang, L., Zhnag, X., and Song, Y. 2019. Preliminary study on Larix spp. infected by Bursaphelenchus xylophilus in natural environment. For. Pest Dis. 38:7-10.
Zhang, J., Zhang, R., and Chen, J. 2007. Species and their dispersal ability of Monochamus as vectors to transmit Bursaphelenchus xylophilus. J. Zhejiang For. Coll. 24:350-356.

Zhang, K., Liang, J., Yan, D., and Zhang, X. 2010. Research advances of pine wood nematode disease in China. World For. Res. 23:59-63. 